\title{
Investigations for the Recycle of \\ Pyroprocessed Uranium
}

\author{
10th International Conference on Molten \\ Slags, Fluxes and Salts (MOLTEN 2016)
}

B. R. Westphal, J. C. Price, E. E. Chambers, M. N. Patterson

February 2016

The INL is a

U.S. Department of Energy

National Laboratory

operated by

Battelle Energy Alliance

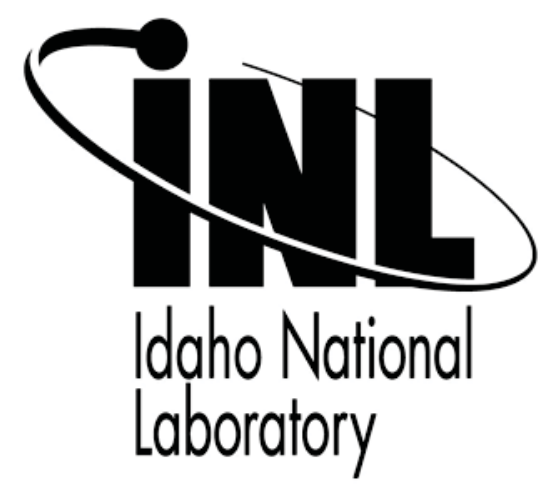

This is a preprint of a paper intended for publication in a journal or proceedings. Since changes may be made before publication, this preprint should not be cited or reproduced without permission of the author. This document was prepared as an account of work sponsored by an agency of the United States Government. Neither the United States Government nor any agency thereof, or any of their employees, makes any warranty, expressed or implied, or assumes any legal liability or responsibility for any third party's use, or the results of such use, of any information, apparatus, product or process disclosed in this report, or represents that its use by such third party would not infringe privately owned rights. The views expressed in this paper are not necessarily those of the United States Government or the sponsoring agency. 



\title{
INVESTIGATIONS FOR THE RECYCLE OF PYROPROCESSED URANIUM
}

\author{
B.R. Westphal, J.C. Price, E.E. Chambers, and M.N. Patterson \\ P.O. Box 1625 \\ Idaho Falls, ID 83415
}

Keywords: Pyroprocessing, Uranium Recycle

\begin{abstract}
Given the renewed interest in uranium from the pyroprocessing of used nuclear fuel in a molten salt system, the two biggest hurdles for marketing the uranium are radiation levels and transuranic content. A radiation level as low as possible is desired so that handling operations can be performed directly with the uranium. The transuranic content of the uranium will affect the subsequent waste streams generated and, thus also should be minimized. Although the pyroprocessing technology was originally developed without regard to radiation and transuranic levels, adaptations to the process have been considered. Process conditions have been varied during the distillation and casting cycles of the process with increasing temperature showing the largest effect on the reduction of radiation levels. Transuranic levels can be reduced significantly by incorporating a pre-step in the salt distillation operation to remove a majority of the salt prior to distillation.
\end{abstract}

\section{Introduction}

During the last twenty years, several nuclear entities have shown various interest levels in the uranium products from the pyroprocessing of used metallic nuclear fuel at the Fuel Conditioning Facility (FCF). The used nuclear fuel originates from the core or driver regions of the retired Experimental Breeder Reactor II (EBR-II) and Fast Flux Test Facility (FFTF) and is highly enriched ( $\sim 60 \%$ U-235) with moderate burnup ( $\sim 10$ atom $\%)$. Inevitably, the two biggest hurdles for marketing the uranium products are radiation levels and transuranic (viz. plutonium) content. Since most of the operations by other entities would not be remotely handled as in FCF, a radiation level as low as possible is desired so that these entities can handle the recycled uranium directly. The transuranic content will affect the subsequent waste streams generated by the entities during the processing of the uranium products and, thus also should be minimized. It should be noted that pyroprocessing technology was originally designed and developed to be performed remotely and without regard to radiation and plutonium levels [1-3]. Thus, retrofitting the process to market uranium presents challenges not anticipated with the original technology. This paper reports on the experimental research in FCF to reduce the radiation and plutonium levels such that the uranium products may be more attractive for other nuclear entities. 


\section{Equipment}

Two unit operations of the pyroprocess have been targeted to reduce the radiation levels and transuranic content by varying the process conditions; the distillation and casting operations. Distillation is performed on electrorefined dendritic material to remove salt from metallic uranium and consolidate the uranium. The casting operation down-blends the fissile content of the uranium and allows sampling of the molten uranium product for chemical analyses. Both operations are performed in a hot cell environment where all tasks are performed remotely with electro-mechanical manipulators.

Figure 1 shows a layout of the distillation equipment, or cathode processor, including splatter shield, process crucible, radiation shield, condenser, and receiver crucible. The furnace region of the cathode processor is heated by a passively cooled induction coil that suscepts to the graphite furnace liner which, in turn, heats the graphite process crucible by radiation. The process crucible is either coated with a slurry of zirconia $\left(\mathrm{ZrO}_{2}\right)$ and dried or has a ceramic liner of zirconia cast into the graphite crucible. A vacuum system is connected to the condenser region and consists of mechanical pumps that are connected to the vessel through an assembly of piping, manifolds, and valves. Distillate material is transferred to the condenser region from the process crucible in the vapor phase and collected in the receiver crucible.

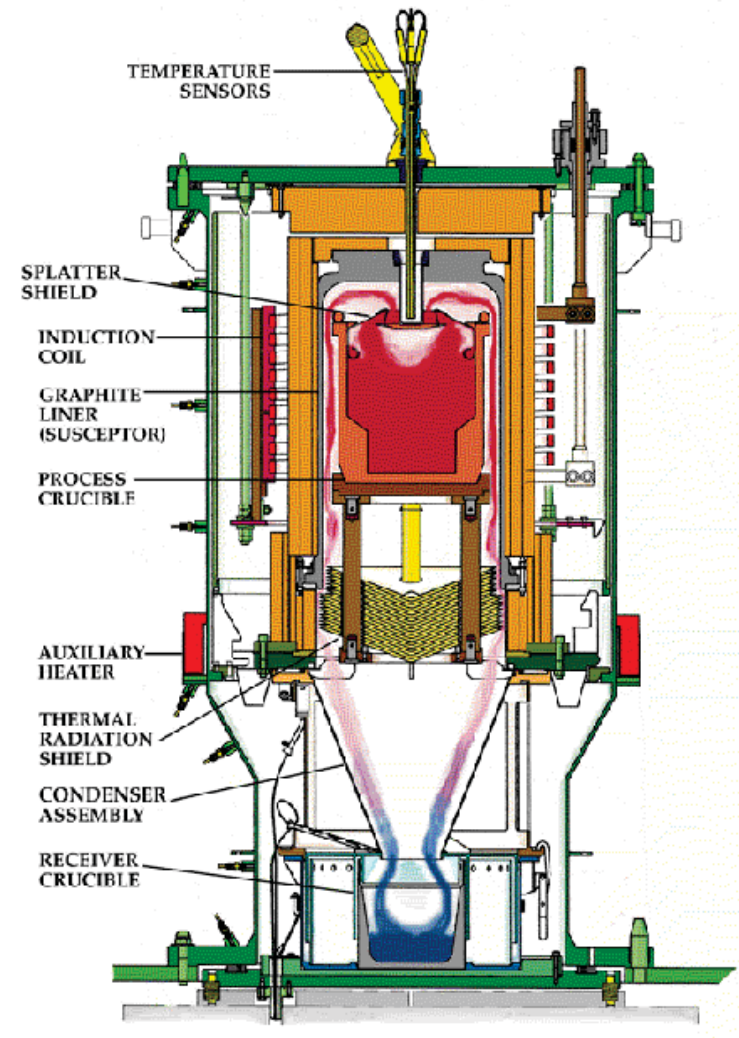

(a)

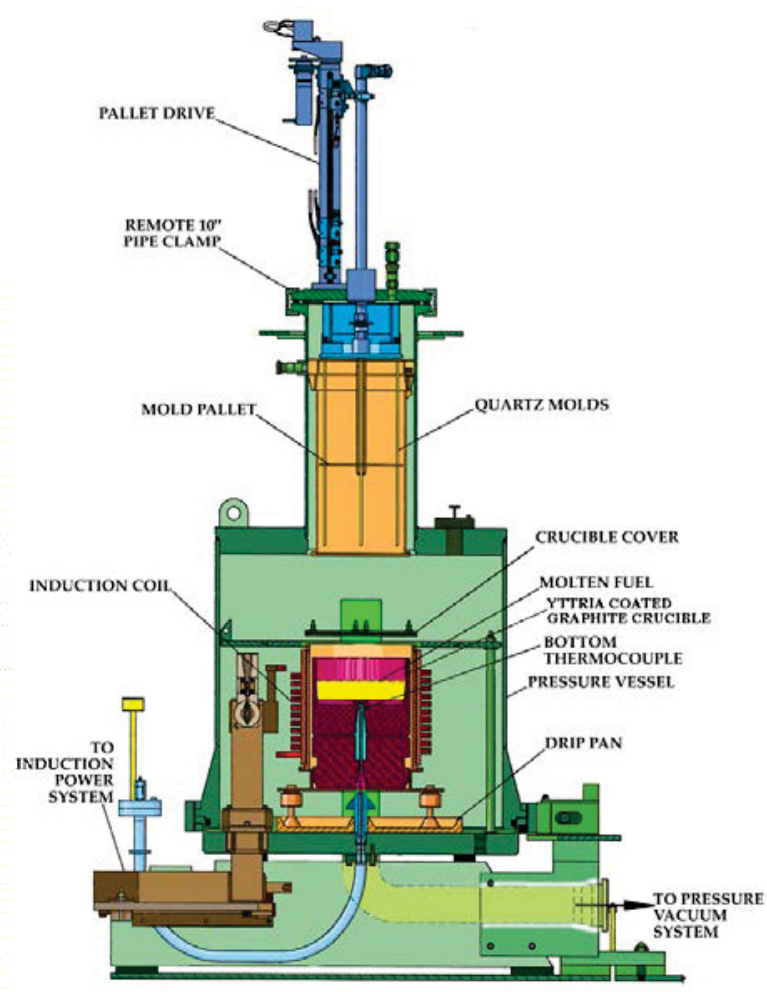

(b)

Figure 1. Schematics of cathode processor (a) and casting furnace (b) 
Testing with irradiated materials in the cathode processor commenced in August 1996 with a batch of enriched dendrites from the Mk-IV electrorefiner [4]. Enriched batch sizes in the cathode processor are less than $20 \mathrm{~kg}$ with an approximate salt fraction of $20 \mathrm{wt} . \%$. As designed, the cathode processor is capable of temperatures as high as $1673 \mathrm{~K}$ and pressures less than $10 \mathrm{~Pa}$. For typical distillations, it is only heated to $1473 \mathrm{~K}$ at less than $100 \mathrm{~Pa}$ to achieve sufficient separation of distillate from the uranium ingots. A more thorough description of the cathode processor equipment and operations is given elsewhere [5].

Also shown in Figure 1 is a schematic of the casting equipment, an inductively-heated furnace capable of melting and casting uranium ingots. A graphite crucible coated with yttria contains the molten uranium from which samples are taken via an evacuation/pressurization cycle. The vacuum capability is instrumental in casting molten metal into quartz molds $(0.43 \mathrm{~cm}$ inside diameter by $41 \mathrm{~cm}$ length). Following a system evacuation, the molds are submerged into the melt and the system is repressurized rapidly to fill the molds. The solidified metal is removed from the molds, sectioned $(0.64 \mathrm{~cm}$ length $)$, and sent to the analytical laboratory for chemical analyses.

More than 100 heats of the casting furnace have been performed to down-blend, sample, and produce uranium products $(20 \mathrm{~cm}$ diameter by approximately $8 \mathrm{~cm}$ height) ranging in size from $15-50 \mathrm{~kg}$ [6]. Additional depleted uranium is utilized for the down-blending to take the enrichment to less than $20 \% \mathrm{U}-235$. The casting furnace is capable of temperatures as high as $1873 \mathrm{~K}$ and vacuums to less than $100 \mathrm{~Pa}$. The uranium products, once characterized by chemical analyses, are being placed in interim storage awaiting final disposition.

Following the dissolution of the solidified metal sections in nitric acid in the analytical laboratory, two different techniques are utilized for the determination of chemical compositions; inductively-coupled plasma mass spectroscopy (ICP-MS) and gamma-ray spectroscopy. The equipment for these techniques has been modified for use with radioactive solutions to limit personnel exposure by their operation in a shielded glovebox and monitoring of the transmission by a spectrometer located exterior to the box.

\section{Radiation Readings of Uranium Products}

There are two methods for measuring the radiation readings from uranium products produced during the treatment of used EBR-II and FFTF fuel; ingot form and pin form. The ingot form measurements are made at several positions on the storage container with the uranium products. Typically the measurements, in $\mathrm{R} / \mathrm{hr}$, from the bottom of the storage container on contact are used for comparison purposes. This measurement is through $0.95 \mathrm{~cm}$ steel plate and usually is performed on the ingot's top surface. The pin form measurements are performed in the analytical laboratory directly on sectioned pin pieces before dissolution for chemical analyses. Shown in Table I are the ingot and pin form data for the three processing campaigns of the driver fuel to date $(\mathrm{U}-10 \mathrm{Zr}$ is a binary uranium-zirconium fuel and $\mathrm{U}-5 \mathrm{Fs}$ is a uranium-fissium alloy where fissium includes $\mathrm{Mo}, \mathrm{Ru}, \mathrm{Rh}, \mathrm{Pd}$, and $\mathrm{Zr}$ ). 
Table I. Radiation readings $(\mathrm{R} / \mathrm{hr} / \mathrm{kg})$ of driver uranium products

\begin{tabular}{|c||c|c|c|}
\hline Form & $\begin{array}{c}\text { EBR-II } \\
\text { U-10Zr }\end{array}$ & $\begin{array}{c}\text { FFTF } \\
\text { U-10Zr }\end{array}$ & $\begin{array}{c}\text { EBR-II } \\
\text { U-5Fs }\end{array}$ \\
\hline \hline Ingot & $0.2(5)$ & $0.1(15)$ & $0.1(3)$ \\
Pin & $1.0(14)$ & $1.8(24)$ & $0.5(3)$ \\
\hline
\end{tabular}

The first value is the radiation reading and the second value in parentheses is the number of units averaged for the data. The data for the ingot form have been adjusted for the $0.95 \mathrm{~cm}$ plate and the slag layer on the top of the ingot so that a direct comparison with the pin form is possible [7]. As seen from the data, the ingot form radiation readings are much lower, presumably due to the self-shielding effects in the ingot form.

The primary contribution to the radiation level is gamma-based Cs- 137 which oxidizes to the electrorefiner salts as cesium chloride [7]. Although the distillation step of pyroprocessing removes the majority $(>99 \%)$ of the salt from uranium, a residual quantity remains that can either react with the oxide-based crucible components to form stable cesium compounds (e.g. $\mathrm{Cs}_{\mathrm{x}} \mathrm{U}_{\mathrm{y}} \mathrm{O}_{\mathrm{z}}$ ) or remain as undistilled cesium chloride. In both instances, the cesium can preferentially accumulate on the surface of uranium products, both ingots and pins, based on the differential cooling characteristics of the products.

Shown in Table II are specific radiation measurements of uranium product batches (FF for FFTF and FS for fissium) with their associated maximum temperatures at the cathode processor (CP) and casting furnace (CF). For consistency, only radiation readings from the bottom of the storage container on contact $(\sim 2.54 \mathrm{~cm})$ are reported in Table II. Radiation readings were only taken following the casting step for the FFTF batches while the fissium batches had measurements taken on both the cathode processor and casting ingots. In general, increasing the maximum temperature at the cathode processor reduced the radiation readings of the casting ingots. Conversely, no significant effect has been seen to date in increasing the temperatures at the casting furnace.

Also included in Table II is the quantity of Cs-137 found from sampling during the casting operation. Since the sampling of uranium ingots is performed during the casting cycle, the amount of Cs-137 detected represents a bulk or homogeneous quantity and may not represent that associated with the top surface of the ingot. Despite the bulk versus surface concern, the amount of Cs-137 in the casting ingots appears to be correlated with the radiation measurements, see Figure 2. Possible sources of errors in the Cs-137 data include analytical, sampling, and cross-contamination from reusable casting crucibles or other casting equipment components. The most significant error in the radiation reading data derives from the measurement location; the reading is a function of the inverse of distance squared. 
Table II. Radiation readings and other data from uranium ingots

\begin{tabular}{|c||c|c|c|c|c|}
\hline & $\begin{array}{c}\text { CP } \\
\text { Maximum } \\
\text { Temperature } \\
\text { Batch }\end{array}$ & $\begin{array}{c}\text { CP Ingot } \\
\text { Radiation } \\
\text { Reading } \\
\text { (R/hr @ 2.54 cm) }\end{array}$ & $\begin{array}{c}\text { CF } \\
\text { Maximum } \\
\text { Temperature } \\
(\mathrm{K})\end{array}$ & $\begin{array}{c}\text { CF Ingot } \\
\text { Radiation } \\
\text { Reading } \\
\text { (R/hr @ 2.54 cm) })\end{array}$ & $\begin{array}{c}\text { Cs-137 in } \\
\text { Product } \\
\text { Ingot } \\
\text { (ppb) }\end{array}$ \\
\hline \hline FF001 & 1473 & Not Measured & 1661 & 28.5 & 62 \\
FF002 & 1473 & Not Measured & 1625 & 16.7 & 2 \\
FF003 & 1473 & Not Measured & 1625 & 10.0 & 50 \\
FF004 & 1473 & Not Measured & 1585 & 19.0 & 43 \\
FF005 & 1623 & Not Measured & 1589 & 3.0 & 15 \\
FF006 & 1623 & Not Measured & 1586 & 4.6 & 9 \\
FF007 & 1473 & Not Measured & 1584 & 1.4 & 13 \\
FF008 & 1473 & Not Measured & 1586 & 0.9 & 9 \\
FF009 & 1623 & Not Measured & 1586 & 1.5 & 6 \\
FF010 & 1623 & Not Measured & 1586 & 0.7 & 7 \\
FF011 & 1473 & Not Measured & 1588 & 21.0 & 40 \\
FF012 & 1473 & Not Measured & 1829 & 24.0 & 11 \\
FF013 & 1623 & Not Measured & 1585 & 0.5 & 9 \\
FF014 & 1623 & Not Measured & 1589 & 4.2 & 5 \\
FF015 & 1623 & Not Measured & 1584 & 2.7 & 6 \\
FS001 & 1503 & 10.7 & 1833 & 7.1 & 16 \\
FS002 & 1623 & 11.4 & 1823 & 11.5 & 23 \\
FS003 & 1473 & 59.6 & 1823 & 34.4 & 260 \\
\hline
\end{tabular}

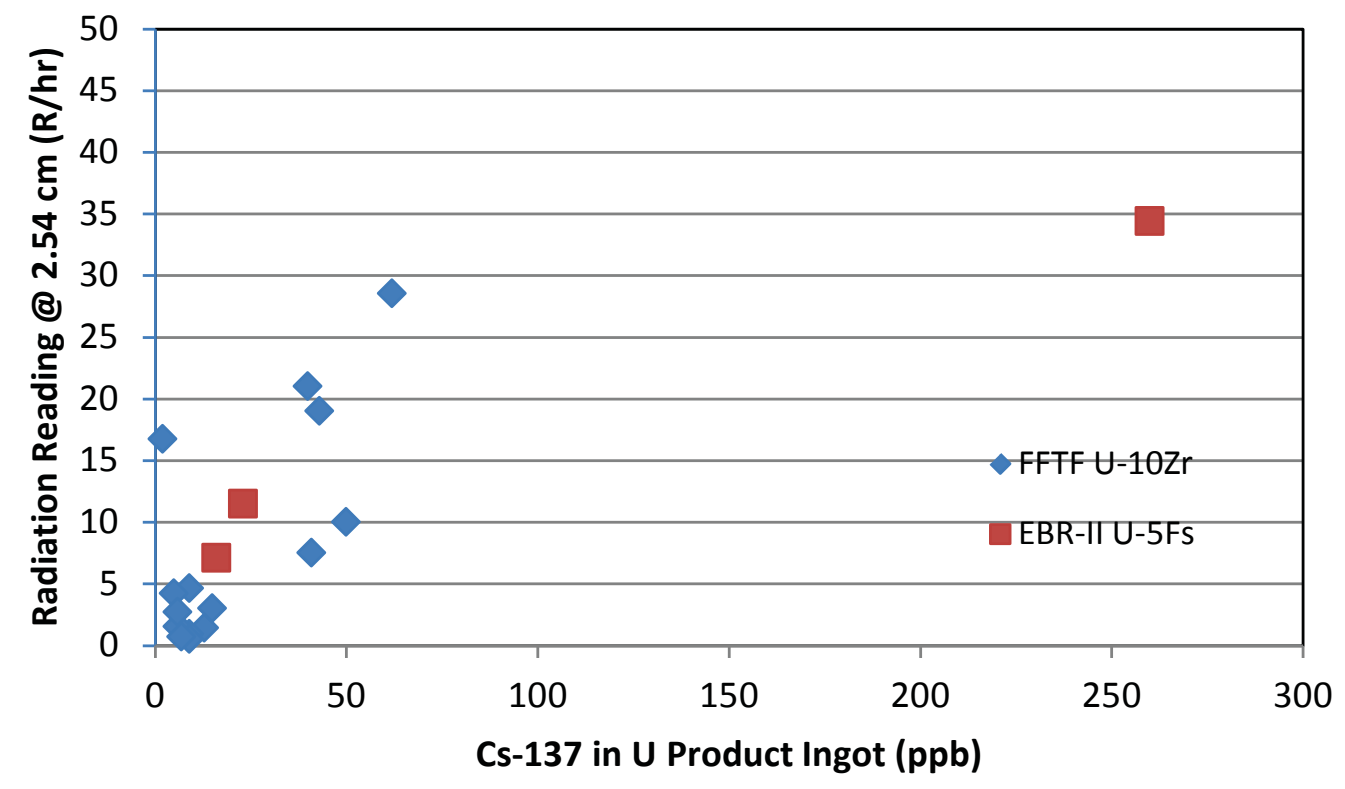

Figure 2. Radiation readings versus Cs-137 in FFTF and EBR-II uranium products 


\section{Plutonium Content of Uranium Products}

The two most recent campaigns of processing driver uranium products in FCF include the FFTF fuel as well as the EBR-II U-5Fs fuel. The plutonium content for these campaigns is shown in Figure 3. In general, the plutonium levels of the uranium products averages about $100 \mathrm{ppm}$ with one ingot as high as $200 \mathrm{ppm}$. Plutonium in the ingots is a result of the reaction of plutonium chloride with uranium metal in the cathode processor according to the following reaction [8]:

$$
\mathrm{PuCl}_{3} \text { (salt) }+\mathrm{U}(\text { metal })=\mathrm{UCl}_{3} \text { (salt) }+\mathrm{Pu} \text { (metal) }
$$

Thermodynamically, this reaction would be driven to the left although the conditions in the cathode processor favor the reaction to the right given the distillation of salt away from metal. Thus, plutonium metal is left as an impurity on the uranium products.

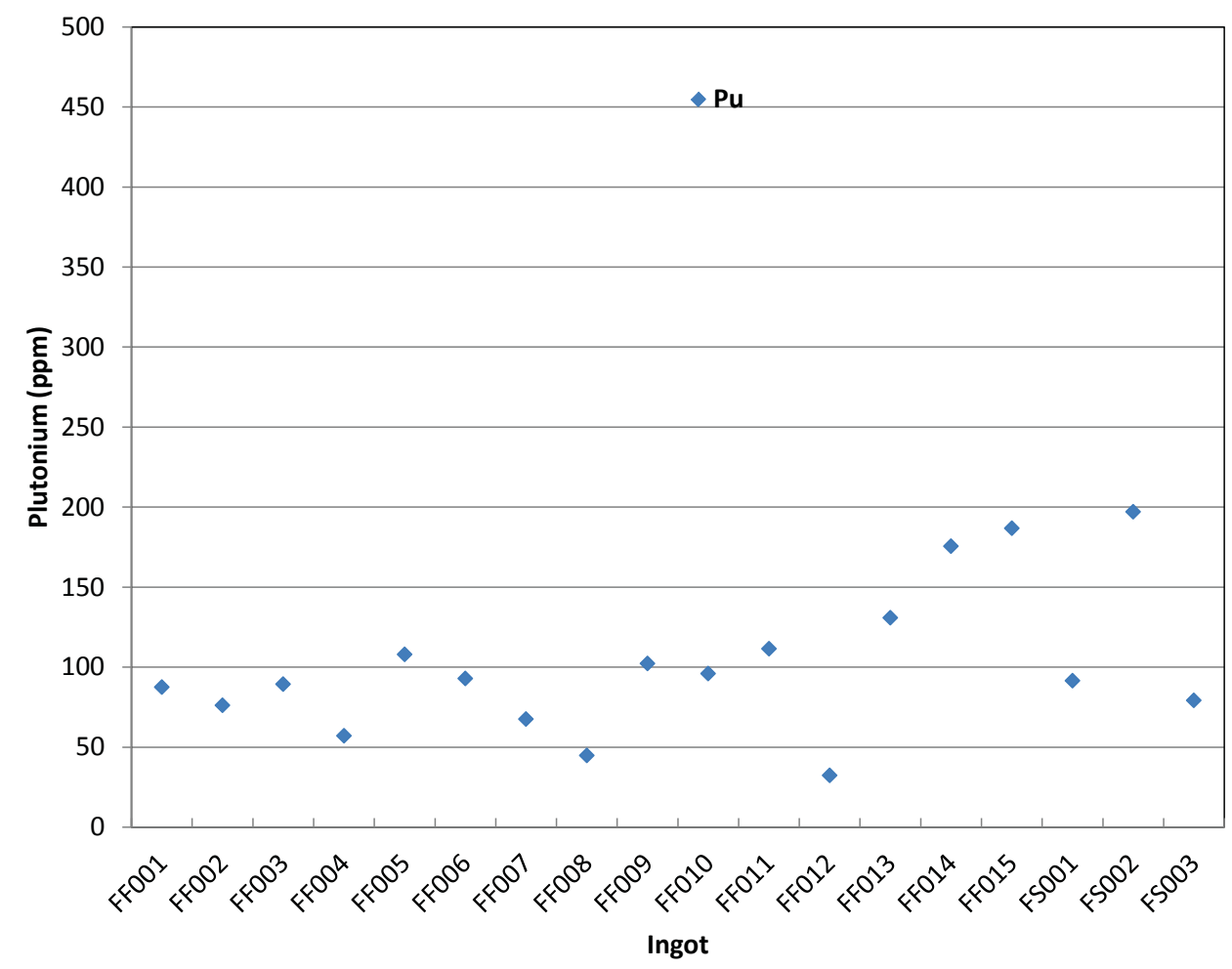

Figure 3. Plutonium levels for FFTF and EBR-II U-5Fs uranium products

Although external entities have not specified an acceptable transuranic (TRU) content, levels as low as 10-20 ppm have been implied based on anticipated process scenarios and subsequent waste stream requirements. Recognizing that approximately $75 \%$ of the TRU elements in the uranium product are plutonium, a plutonium value of $15 \mathrm{ppm}$ is targeted as a requirement for the product specification. Additional contributing TRU elements would be neptunium (Np-237) and americium (Am-241). Given the current level of plutonium in the uranium products, a reduction by a factor of approximately seven would be required to meet this specification. 
Since the plutonium in the uranium products originates from the salt, a scoping set of experiments was performed in FCF to remove a fraction of the salt prior to distillation and observe the effects on plutonium contamination. An additional benefit of salt removal may be a reduction in the cesium levels of the uranium products and hence, the radiation levels, since cesium is present as a distillable chloride species. The basis for the pre-distillation salt removal tests has been demonstrated previously [9]. Although the investigation was with salt only and not dendritic material, salt removals of $73 \%$ at $773 \mathrm{~K}$ and $94 \%$ at $873 \mathrm{~K}$ were realized.

Two tests were performed with dendritic material loaded into a screened bucket in the FCF cathode processor to demonstrate the feasibility of salt draining. The screen material was 100 mesh welded to the bottom of the bucket supported by a plate with $0.64 \mathrm{~cm}$ diameter holes. Following each test, the consolidated dendrites were removed from the bucket and loaded into a normal cathode processor crucible for distillation of the remaining salt.

For the first test, approximately $7.3 \mathrm{~kg}$ of dendritic material from the Mk-IV electrorefiner was loaded into the bucket and heated to 873,973 , and $1073 \mathrm{~K}$ for 1 hour during three separate salt draining heats in the cathode processor. In between the heats, weight measurements were taken on the bucket to assess the amount of salt draining. The bucket was placed on a graphite ring which resided on the graphite crucible stand in the lower region of the cathode processor coil. Shown in Figure 4 are photographs of the bucket prior to the $873 \mathrm{~K}$ run and following the 1073 $\mathrm{K}$ run. Note the consolidation of the dendrites between the three runs. For the three runs, $428 \mathrm{~g}$, $51 \mathrm{~g}$, and $90 \mathrm{~g}$ of salt were removed per run, respectively. An additional $373 \mathrm{~g}$ of salt was removed during a final distillation run to $1473 \mathrm{~K}$ in a separate crucible for a total of $942 \mathrm{~g}$ of salt. Thus, the amount of salt removed by salt draining was approximately $44 \%$ by weight of the total.

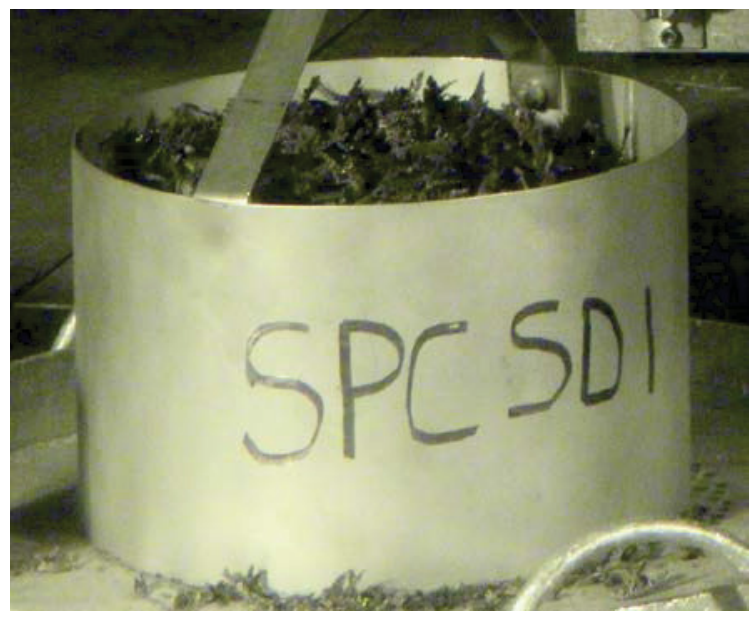

(a)

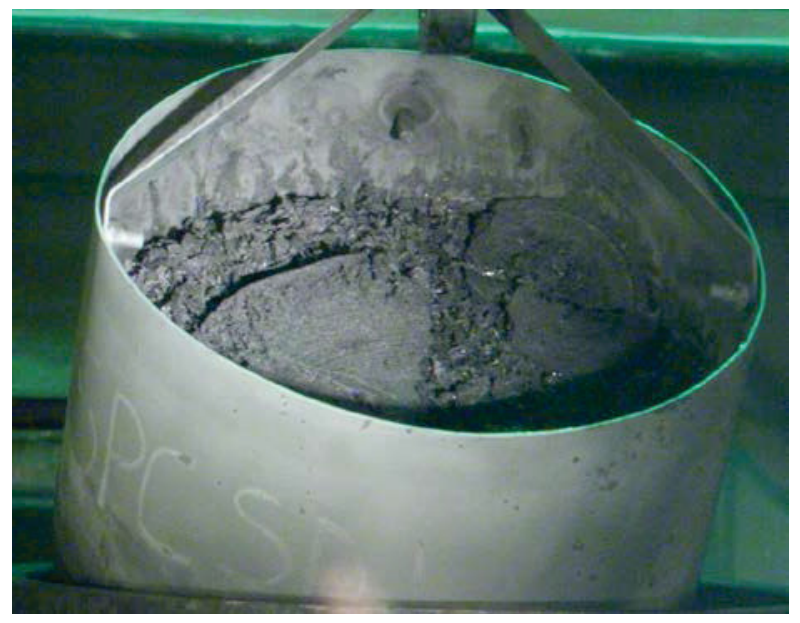

(b)

Figure 4. Photographs of first salt draining test before 873 K (a) and after 1073 K (b)

For the second test, approximately $7.2 \mathrm{~kg}$ of dendritic material from the Mk-IV electrorefiner was loaded into a new second bucket and heated to $1073 \mathrm{~K}$ for 1 hour in the cathode processor. After the run, a weight measurement was taken on the bucket to assess the amount of salt 
draining. For this test, the bucket was placed inside a graphite crucible which placed the bucket in the upper region of the cathode processor coil. The consolidation of the dendrites was noted as similar to the previous test. For the run, $581 \mathrm{~g}$ of salt was removed from the bucket and collected in the bottom of the graphite crucible. An additional $750 \mathrm{~g}$ of salt was removed during the final distillation run in a separate crucible for a total of $1331 \mathrm{~g}$ of salt. Thus, salt draining removed approximately $60 \%$ of the total salt. Although the casting operations for the two salt draining tests have not yet been performed, it is anticipated that with a reduction of salt between $44-60 \%$ that the plutonium levels would be reduced similarly. Future salt draining tests will extend the hold times and maximize dendrite/screen contact area in an effort to improve salt removal.

\section{Conclusions}

- Based on the radiation readings taken on the casting ingots, increasing the cathode processing operating temperature resulted in reduced radiation levels.

- Although testing to reduce the radiation levels of uranium products continues, adjustment of the cathode processor operating conditions has had more of an effect than on the casting conditions.

- Radiation readings of uranium products in their storage containers appear to be dependent on the bulk Cs-137 levels in the product ingots.

- Salt removals as high as $60 \%$ by a draining operation should result in a significant improvement in the transuranic levels of the uranium products.

\section{Acknowledgements}

The authors would like to acknowledge the Fuel Conditioning Facility operations personnel for their contributions and the Analytical Laboratory staff for chemical services. This work was supported by the U.S. Department of Energy, Office of Nuclear Energy, Science, and Technology, under DOE-NE Idaho Operations Office Contract DE-AC07-05ID14517.

\section{References}

[1] Y.I. Chang, "The Integral Fast Reactor," Nucl. Tech., 88 (1990), 129-138.

[2] C.E. Till and Y.I. Chang, Plentiful Energy - The Story of the Integral Fast Reactor (Charleston, SC: CreateSpace, 2012).

[3] R.W. Benedict and H.F. McFarlane, "EBR-II Spent Fuel Demonstration Project Status," Radwaste, 5, 23 (1998).

[4] S.X. Li et al., "Electrorefining Experience for Pyrochemical Processing of Spent EBR-II Driver Fuel," Proc. GLOBAL 2005 (Tsukuba, Japan: AESJ, 2005), 487.

[5] B.R. Westphal et al., "On the Development of a Distillation Process for the Electrometallurgical Treatment of Irradiated Spent Nuclear Fuel," Nucl. Eng. Tech., 40 (2008), 163-173. 
[6] B.R. Westphal et al., "Zirconium Determination by Cooling Curve Analysis during the Pyroprocessing of Used Nuclear Fuel," J. Nucl. Mat., 457 (2015), 241-245.

[7] B.R. Westphal et al., "Radiation Measurements of Uranium Ingots from the Electrometallurgical Treatment of Spent Fuel” (Report ANL-NT-188, Argonne National Laboratory Report, 2001).

[8] B.R. Westphal et al., "Transformation of Uranium Products from the Pyrometallurgical Processing of Used Nuclear Fuel," Proc. Pu Futures-The Science 2010 (Keystone, CO: ANS, 2010), 352-353.

[9] K.M. Park et al., "The Solid-Liquid Separation Characteristics of Pure LiCl-KCl Eutectic Salt using Different Types of Crucibles," J. Radioanal. Nucl. Chem., 295 (2013), 11871193. 